\title{
ANALYSIS OF PERSONAL NARRATIVES
}

\author{
Catherine Kohler Riessman \\ Boston University \\ Riessman@bu.edu
}

April 20, 2000

To appear in Handbook of Interviewing, edited by J.F. Gubrium and J.A. Holstein, Sage Publications, 2001.

For comments on an earlier version of the chapter, I thank Elliot Mishler, Paul Rosenblatt, Jay Gubrium and Jim Holstein. The Narrative Study Group provided valuable input into my analysis of Gita's narrative. 
It is a common experience for investigators to carefully craft interview questions, only to have participants respond with lengthy accounts - long stories that appear, on the surface, to have little to do with the question. I became aware of the issue in the early 1980 s while researching the topic of divorce. After completing a household interview with a divorcing spouse, I would note that a respondent had gone "on and on." Asking a seemingly straightforward question (e.g. "what were the main causes of your separation"), I expected a list but, instead, got a "long story." Those of us on the research team interpreted the stories as digressions.

Subsequently, I realized that participants were resisting our efforts to fragment their lived experience into thematic (code-able) categories—our attempts to control meaning. There was a typical sequence to the moments of resistance: the "long story" began with the decision to marry, moved through the years of the marriage, paused to reenact particularly troubling incidents, and ended often with the moment of separation (Riessman 1990b). Although participants resisted our efforts to contain their lengthy narratives, they were very aware of the rules of conversational storytelling. After coming to the end of a long and complex story of a marriage, a participant would sometimes say "uh, I'm afraid I got a little lost. What was the question you asked?" With such "exit talk," the interviewer could move onto the next question.

Looking back, I am embarrassed and instructed. The incidents vivify the gap between the standard practice of research interviewing in social research, and the life world of naturally occurring conversation (Mishler 1986), and human relationships. Although dehumanizing research practices persist, feminists and others in the social sciences have cleared a space for less dominating and more relational modes of 
interviewing, which reflect (and respect) participants ways of organizing meaning in their lives (DeVault 1999). We have made efforts to give up power, and follow participants down their associative trails. The current wellspring of interest in personal narrative reflects these trends.

\section{THE NARRATIVE TURN}

The burgeoning literature on narrative has touched almost every discipline and profession in the U.S. No longer the province only of literary study, the "narrative turn" in the human sciences has entered history (Carr 1986; Cronon 1992; White 1987), anthropology and folklore (Behar 1993; Mattingly and Garro 2000; Rosaldo 1989; Young 1987), psychology (Bruner 1986, 1990; Mishler 1986, 1999a; Polkinghorne 1988; Rosenwald and Ochberg 1992; Sarbin 1986), sociolinguistics (Capps and Ochs 1995; Gee 1986, 1991; Labov 1982; Linde 1993), and sociology (Bell 1988, 1999, 2000; Chase 1995; Boje 1991; DeVault 1991; Frank, 1995; Holstein and Gubrium 2000; Williams 1984). The professions, too, have embraced the narrative metaphor, along with investigators who study particular professions: law ("Legal Storytelling" 1989), medicine (Charon 1986; Greenhalgh and Hurwitz 1998; Hunter 1991; Hyden 1997; Kleinman 1988), nursing (Sandelowski 1991), occupational therapy (Mattingly 1998), and social work (Dean 1995; Laird 1988). Storytelling, to put the argument simply, is what we do with research and clinical materials, and what informants do with us. The approach does not assume objectivity but, instead, privileges positionality and subjectivity. 
Narrative analysis takes as its object of investigation the story itself. I limit discussion here to first-person accounts in interviews of informants' experience, ${ }^{i}$ putting aside other kinds of narratives (e.g. about the self of the investigator, what happened in the field, media descriptions of events, or the "master narratives" of theory). My research has focused on disruptive life events, accounts of experiences that fundamentally alter expected biographies. I have studied divorce, chronic illness, and infertility, and draw on these examples later.

Narrative analysis, however, is not only relevant for the study of disruptive life events: the methods are equally appropriate for studies of social movements, political change, and macro-level phenomena. Because storytelling "promotes empathy across different social locations", in the U.S. abortion debate Gamson (1999:5) argues that storytelling has counteracted excessive abstraction, bridging policy discourse and the language of women's life worlds; storytelling has fostered the development of constituencies - communities of action. Plummer puts it vividly (1995: 174): "stories gather people around them“, dialectically connecting people and social movements. The identity stories of members of historically "defiled" groups (rape victims, gays and lesbians) reveal shifts in language over time, which shaped (and were shaped by) the mobilization of these actors in collective movements, such as "Take Back the Night" and gay rights groups. "For narratives to flourish there must be a community to hear; ...for communities to hear, there must be stories which weave together their history, their identity, their politics" (Plummer 1995:87).

Storytelling is a relational activity that gathers others to listen and empathize. It is a collaborative practice, and assumes tellers and listeners/questioners interact in 
particular cultural milieux - historical contexts essential to interpretation. Analysis in narrative studies opens up forms of telling about experience, not simply the content to which language refers. We ask, why was the story told that way? (Riessman 1993).

Study of personal narrative is a form of case-centered research (Mishler 1999a). Building on the tradition of sociology articulated most vividly by C.W. Mills (1959), the approach illuminates the intersection of biography, history, and society. The "personal troubles" that participants represent in their narratives of divorce, for example, tell us a great deal about social and historical processes - contemporary beliefs about gender relations and pressures on marriage at a juncture in American history (Riessman, 1990b). Coming out stories, similarly, where narrators proclaim their gayness to themselves and others, reveal a shift in genre over time: the linear, "causal" modernist tales of the " $60 \mathrm{~s}$ and '70s give way in contemporary stories to identities that blur and change (Plummer 1995). Historical shifts in understanding and growing politicization occur in the stories of women with cancer whose mothers were exposed to DES during pregnancy (Bell 1999). Illness narratives reveal "deeply historicized and social view[s] of health and illness", as Skultans (1999:322) shows with post-Soviet women patients' accounts of hardship - explanations erased in their physicians' (biomedical) definitions of problems. As Mills said long ago, what we call "personal troubles" are located in particular times and places, and individuals' narratives about their troubles are works of history, as much as they are about individuals, the social spaces they inhabit, and the societies they live in. Analysis of personal narratives can illuminate "individual and collective action and meanings, as well as the social processes by which social life and human relationships are made and changed" (Laslett 1999:392). 


\section{LOCATING NARRATIVES FOR ANALYSIS}

There is considerable variation in how investigators employ the concept of personal narrative and, relatedly, in methodological assumptions and strategies of analysis. These, in turn, are usually tied to disciplinary background. In one tradition of work (typical of social history and anthropology), narrative refers to the entire life story, an amalgam of autobiographical materials. Barbara Myerhoff's (1978) work offers an early example of the life story approach, and well illustrates its potentials and problems. She constructs compelling portraits of elderly Eastern European Jews, living their remaining lives in Venice, California, from the many incidents informants shared with her during extended fieldwork. She artfully "infiltrates" the other, "depositing her authorial word inside others' speech" to speak her truth without "erasing the others' viewpoint and social language" (Kaminsky 1992:17-18). In this genre, the stories informants recount merge with the analyst's interpretation of them, sometimes to the point of being indistinguishable.

In a very different tradition of work, the concept of personal narrative is quite restrictive, used to refer to brief, topically specific stories organized around characters, setting, and plot. These are discrete stories told in response to single questions; they recapitulate specific events the narrator witnessed or experienced. Labov (1982), for example, analyzes the common structures underlying a series of bounded (transcribed) stories of inner-city violence told in response to a specific question. Narrators recapitulate sequences of action that erupt and bring the danger of death. The approach 
has been extended by others, who include more than brief episodes, to analyze a variety of experiences (Attanucci 1991; Bamberg 1997a; Bell 1988; Riessman 1990a).

In a third tradition, personal narrative refers to large sections of talk and interview exchanges--extended accounts of lives that develop over the course of interviews. The discrete story as the unit of analysis of the second tradition gives way in the third one to an evolving series of stories that are framed in and through interaction. Mishler (1999a), for example, studied the trajectories of identity development among a group of artistcraftspersons that emerged from his extended interviews with them. The approach is distinguished by the following features: presentation of and reliance on detailed transcripts of interview excerpts; attention to the structural features of discourse; analysis of the co-production of narratives through the dialogic exchange between interviewer and participant; a comparative approach to interpreting similarities and differences among participants' life stories. (Also see Bell 1999). In sum, there is considerable diversity in the definition of personal narrative in social research, and consequently large methodological variation. My own work draws on the last two traditions-discrete story and extended account. (For more on the life story approach, see ------ in this volume).

Despite differences, most investigators share some basic understandings. Narration is distinguished by ordering and sequence; one action is consequential for the next. Narrators create plots from disordered experience, ${ }^{\text {ii }}$ giving reality "a unity that neither nature nor the past possesses so clearly" (Cronon 1992:1349). Relatedly, narrators structure their tales temporally and spatially; "they look back on and recount lives that are located in particular times and places" (Laslett 1999:392). Temporal 
ordering of a plot is most familiar (and responds to the characteristic Western listener's preoccupation with forward marching time_-“and then what happened?"), but narratives can also be organized thematically and episodically (Gee 1991; Michaels 1981; Riessman 1987). Narrators use particular linguistic devices to hold their accounts together and communicate meaning to listeners (for a review see Riessman 1993:18-19). Human agency and imagination are vividly expressed:

"With narrative, people strive to configure space and time, deploy cohesive devices, reveal identity of actors and relatedness of actions across scenes. They create themes, plots, and drama. In so doing, narrators make sense of themselves, social situations, and history" (Bamberg and McCabe 1998:iii).

If all talk in interviews is not narrative (there are questions and answers about demographic facts, listings, chronicles, and other non-narrative forms of discourse), how does an investigator identify narrative segments for analysis? Sometimes the decision is clear: informants signal a story is coming and indicate when it is over with entrance and exit talk (Jefferson 1979). In my divorce interviews, for example, responding to a question about the "main causes" of separation, one man provided a listing, and then said, "I'll clarify this with an example", an utterance that introduced a lengthy story about judging a dog show_ an avocation his wife did not share. He exited from the story many minutes later: "That is a classic example of the whole relationship... she chose not to be with me." Particularly vivid, I used the story along with others to theorize about gender 
differences in expectations of companionate marriage in the contemporary U.S. (Riessman 1990b:102-8).

Stories in research interviews are rarely so clearly bounded, and often there is negotiation between teller and listener about placement and relevance, a process that can be analyzed with transcriptions that include paralinguistic utterances ("uhms"), false starts, interruptions, and other subtle features of interaction. Deciding which segments to analyze and putting boundaries around them is an interpretive decision, shaped in major ways by theoretical interests. Deciding beginnings and endings of narratives is often a complex interpretive task.

I confronted the problem in a study of stigma and infertility, as I began to analyze a woman's narrative account of her multiple miscarriages. The research was conducted in Kerala, South India, and elsewhere (Riessman 2000a, 2000b) I describe the fieldwork in detail. At a certain point in the project, I began to focus on identity development for women beyond childbearing age— how older women construct identities that defy stigma and the master narrative of motherhood. Here, I present a portion of an interview with a woman I call "Gita": 55-years-old, married and childless, Hindu, and from a lower caste. Because of progressive social policies and related opportunities in her South Indian state, Gita is educated, has risen in status, and works as a lawyer in a small municipality. The particular interaction represented in the extract took place after she and I had talked (in English) for nearly an hour in her home about a variety of topics (most of which she introduced)--her schooling career, how her marriage was arranged, and her political work in the "liberation struggle of Kerala." We enter the interview as I re-introduce the topic of infertility. My transcription conventions are 
adapted from Gee (1986): lines about a single topic are grouped into stanzas, which I then group into scenes. ${ }^{\text {iii }}$

\section{[TRANSCRIPT 1 ABOUT HERE]}

Although my question (“were you ever pregnant?”) could have been answered directly ("yes"), Gita chose instead to negotiate a space in the interview to develop a complex narrative. She describes terminated pregnancies, going to a political demonstration, coming home to her husband's anger, whereupon the scene shifts to the actions of in-laws' and her husband's refusal to be examined for infertility. It was unlike other women's accounts about failed pregnancies in my interviews. Although temporally organized, Gita's plot spans many years and social settings, and emotions related to the events are absent - there is no reference to sadness, disappointment, or other emotions common to narratives of miscarriage and infertility. In an effort to interpret the segment, I struggled to define its boundaries. Initially, I decided to end my representation of the narrative with what seems like a coda at the end of scene 4: "But afterwards I never became-[pregnant]." The utterance ends the sequence about pregnancies - the topic of my initial question. Ultimately, however, I decided to include the next scene, which communicates various family members' responses, and the reported speech of Gita's husband ("No, no, I will not go to a lady doctor"). The shift in my decision about the boundaries of the narrative coincided with a theoretical shift in my thinking about identity construction. I became interested in how stigma is resisted by South Indian women when infertility occurs (Riessman 2000b). It was crucial, then, to include the episode about the in-laws, the interaction with the gynecologist, and the husband's response to the request that he be tested. 
Although not my focus here, the narrative excerpt could be analyzed as an interactional accomplishment, that is, as the joint production of interviewer and respondent. Such a focus would require re-transcription to include all my utterances (deleted and marked "=" in the excerpt), the ways I elicited and shaped the narrative. (For examples of the approach, see Bell 1999; Capps and Ochs 1995; Mishler 1997; Riessman 1987). The narrative could be analyzed with a primary focus on cultural context - the prominent role of the wife's in-laws, for example, in defining and managing infertility in India. (For an example, see Riessman 2000a.) The narrative could be analyzed in terms of problems it solves for the narrator - an angle into the text I develop shortly--and other problems that it creates. Investigators interested in psychological processes, narrative therapy and change (White and Epston 1990; Josselson and Lieblich 1993; McLeod 1997) might explore Gita's account of infertility for its closed, sealed-off features - she displays a set of understandings that seem to defy re-definition and change. Silence about emotions might be a focus.

The construction of a narrative segment for analysis - the representations and boundaries we chose - are strongly influenced by our evolving theories, disciplinary preferences, and research questions. In all these ways, the investigator "infiltrates" her texts. Unlike the life story tradition noted earlier, however, my approach here includes detailed transcripts of speech so that readers can, to a much greater degree, see the stories apart from the analysis of them. ${ }^{\text {iv }}$ The selves of storyteller and analyst can remain separate (Laslett 1999). 


\section{ANALYZING NARRATIVE AS PERFORMANCE}

Personal narratives serve many purposes--to remember, argue, convince, engage, or entertain their audience (Bamberg and McCabe 1998). Consequently, investigators have many points of entry: personal narratives can be analyzed textually (Gee 1986; Labov, 1982), conversationally (Polanyi 1985), ${ }^{\mathrm{v}}$ culturally (Rosaldo 1989; Mattingly and Garro 2000), politically/historically (Mumby 1993; White 1987), and performatively (Langellier 1989). It is the latter theoretical position I primarily emphasize here. A story involves storytelling--a reciprocal event between a teller and an audience. When we tell stories about our lives we perform our (preferred) identities (Langellier 2001).

As Goffman $(1969 ; 1981)$ suggests with his repeated use of the dramaturgical metaphor, social actors stage performances of a desirable self to preserve "face" in situations of difficulty, thus managing potentially "spoiled" identities. Relatedly, gender identity is performed, produced for (and by) audiences in social situations. To emphasize the performative element is not to suggest that identities are inauthentic, only that they are situated and accomplished in social interaction.

Applying these insights to interviews, informants negotiate how they want to be known by the stories they develop collaboratively with audiences. Informants do not "reveal" an essential self as much as they perform a preferred self, selected from the multiplicity of selves or persona that individuals switch between as they go about their lives. Approaching identity as a "performative struggle over the meanings of experience" (Langellier 2001:3) opens up analytic possibilities that are missed with static conceptions of identity, and essentializing theories that assume the unity of an "inner" self. 
Personal narratives contain many performative features that enable the "local achievement of identity" (Cussins 1998). Tellers intensify words and phrases, they enhance segments with narrative detail, reported speech, appeals to the audience, paralinguistic features (“uhms") and gestures, or body movement (Bauman 1986). Analysts can ask additional questions of a narrative segment in terms of performance: in what kind of a story does a narrator place herself? How does she position herself to the audience, and vice versa? How does she position characters in relation to one another, and in relation to herself? How does she position herself to herself, that is, make identity claims? (Bamberg 1997b) Social positioning in stories- - how narrators chose to position audience, characters, and themselves — is a useful point of entry because "fluid positioning, not fixed roles, are used by people to cope with the situations they find themselves in" (Harre and van Langenhove 1999:17).

Narrators can position themselves, for example, as victims of one circumstance or another in their tales, giving over to other characters the power to initiate action, not themselves. Alternatively, narrators can position themselves as agentic beings that assume control over events and actions: they purposefully initiate and cause action. They can shift among positions, giving themselves agentic roles in certain scenes, and passive roles in others. To create these fluid semantic spaces for themselves, narrators use particular grammatical resources to construct who they are- - verbs, for example, that frame actions as voluntary rather than compulsory, or grammatical forms that intensify vulnerability (Capps and Ochs 1995). These positionings of the self in personal narratives signify the performance of identity. They are enacted in an immediate 
discursive context, the evolving interview with a listener/questioner, and can be analyzed with detailed transcriptions.

I illustrate this approach to analysis by returning to Gita's narrative account (see Transcript 1). In the larger research project I show how the cultural discourse of gender defines women by their marital and childbearing status, and in South India married women face severe stigma when they cannot (or chose not to) reproduce (Riessman 2000b). Self-stigma was a recurring theme in my interviews, even as historical developments in contemporary India are enabling some women to resist the "master narrative" of motherhood. Gita deviated from the general pattern: she was beyond childbearing age, the absence of motherhood did not seem to be a particularly salient topic for her (I was always the one to introduce it), and she did not express sadness or negative self-evaluation, as younger women did. It turned out Gita had built a life around principles other than motherhood - she is a lawyer and political activist. Close examination of the narrative reveals precisely how she constructs this preferred (positive) identity — solving the problem of stigma and subordination as a childless women in South India. She resists the dominant cultural narrative about gender identity with an autobiographical narrative that transforms a personal issue into a public one (Richardson 1990).

Gita carefully positions the audience (me) and various characters in the discursive construction of the story - a complex performance that I have represented in five "scenes." Each offers a snapshot of action, located in a different time and setting. Unlike narratives in the discrete story tradition (Labov 1982), there is a complex organization to 
Gita's narrative. Attention to how scenes are organized within the performance is my analytic point of entry.

The first two scenes are prompted by an audience request ("were you ever pregnant?") - my attempt to position Gita in a world of fertility. She reluctantly moves into the role of pregnant woman in these brief scenes, quickly chronicling two pregnancies several years apart — the outcomes of which I have to clarify (in lines deleted from the transcript). She does not provide narrative detail, elaborate meanings, or describe emotions associated with the miscarriages--the audience must infer a great deal. Gita constructs the first two scenes with only one character beside herself, her doctor. She "approached" the doctor, who "asked" her to have a D\&C. A quick aside states the doctor wanted to examine the husband, but we infer this did not happen. (With this utterance, Gita prefigures her husband's responsibility, anticipating the final scene and the moral of the narrative.) She casts the doctor again as the active agent in scene 2: she "wanted" and "advised" bed rest. By choice of verbs and positioning of characters, Gita constructs scenes in which she has a relatively minor role. The audience infers from the lack of narrative detail that the events in the plot up to this point are not particularly salient for Gita.

The narrator's position and the salience of the events radically change in the third scene. Gita shifts topics, from pregnancy to "to what I already told you" - the primacy of her political world. She constructs a scene where she is the central character, the agent of action, a "political leader" in her Kerala community who "had to" participate in a demonstration in Delhi against Mrs. Indira Gandhi, who was seeking re-election. Verbs frame the narrator's intentional actions, ${ }^{\mathrm{vi}}$ situated in political exigencies, and there is 
considerable narrative elaboration in sharp contrast to the spare, "passive" grammar of the previous scenes, where Gita was the object of the doctor's actions. Gita locates her private fertility story in the larger public story of India's socialist movement- the audience is not left wondering which is most important. Ignoring her doctor's advice "to take bed rest" during her second pregnancy, she travels to Delhi to participate in a mass demonstration, which probably involved a 3-day train trip in 1975. Despite her return by plane and a 16-day nursing home stay for "bleeding," the audience infers that Gita lost the pregnancy (a fact I confirm a few lines later). She constructs a narrative around oppositional worlds—-family life, on the one hand, and the socialist movement of India on the other. The personal and the political occupy separate spheres of action.

Gita shifts the plot in the next two scenes to the family world. In scene 4, she again introduces her husband as a character, and reports that he was "very angry" at her "social work," meaning her political activism. She communicates a one way conversation--Gita does not give herself a speaking role, she positions herself only as the object of her husband's angry speech. We do not know what she said to him, if anything. Her passive positioning in this scene is in sharp contrast to her activity in the previous one. Is she displaying here the typical practice in South Indian families- wives are expected to defer to husbands' authority (Riessman 2000b)? If so, her choice of language is instructive — he said "this and that." Could she be belittling her husband's anger and directives? She concludes scene 4 with a factual utterance ("But afterwards I never became-[pregnant]").

In the fifth and final lengthy scene, Gita introduces new characters (her parents inlaw, an infertility specialist, a sister-in-law) and an intricate plot, before the narrative 
moves toward its moral point — infertility is not Gita's responsibility. The final scene has the most elaboration, suggesting importance; Gita's performance of identity is vivid here.

She begins by constructing a passive, stigmatized position for herself: in-laws "brought" her for treatment to a gynecologist in the major South Indian city where the parents live, because "they thought I had some defect." As in earlier scenes involving pregnancy, others suggest or initiate action. ${ }^{\text {vii }}$ She intensifies meaning and thematic importance with repetition ("defect") in the next stanza - the gynecologist determined after a lengthy examination that Gita has "no defect at all." She is "perfectly" normal. Blame for infertility, Gita intimates, resides elsewhere. Uses the linguistic device of reported speech, she performs several conversations on the topic of getting her husband tested. Everyone is enlisted in the effort — gynecologist, sister-in-law_-but he refuses: "No, no, I will not go to a lady doctor." Nor is he willing to have his sperm tested in a laboratory. (Gita returned several other times in our interview to his refusal to be tested.) The narrator has crafted a narrative performance in which she has no responsibility whatsoever. ${ }^{\text {viii }}$

Readers might question Gita's attributions. She ignored her physician's advice to "take bed rest" during her second pregnancy, choosing to travel instead to Delhi. She gave primacy to political commitments, valuing work in the socialist movement over her gendered position in the home. She was also " 40 or 41 " years old when she was finally examined by a specialist. Age may have been a factor. Gita had conceived twice, but could not sustain pregnancies_-suggesting a possible "defect." 
Gita's performance, however, suggests how she wants to be known, her preferred self-a "perfectly" normal woman "with no defect at all." The way she organizes scenes within the narrative performance, choices about positioning, and the grammatical resources she employs, put forth the preferred identity—committed political activist, not disappointed would-be mother. Later in the interview, she supported this interpretation. Resisting (once again) my positioning of her in the world of biological fertility, she said explicitly: "Because I do not have [children], I have no disappointments, because mine is a big family." She continued with a listing of many brothers, their children, and particular nieces who "come here every evening...to take their meals." With these words, she challenged my bipolar notions of parental status - either you have children or you don't. She performs a gender identity that resists the master cultural narrative--biological motherhood is the central axis of identity for women. Elsewhere (Riessman 2000b) I historicize Gita's life chances, and locate her in an evolving cultural discourse about women's "proper" place in modern India, a "developing" nation that is developing new spaces (besides home and field) for women to labor.

The analytic strategy demonstrated here is generalizable. Narrators can emplot events in their lives in a variety of ways; they "select and assemble experiences and events so they contribute collectively to the intended point of the story... why it is being told, in just this way, in just this setting (Mishler 2000:8). How narrators accomplish their situated stories conveys a great deal about the presentation of self (Goffman 1969). To make the process visible, we analyze scenes in relation to one another, how narrators position characters, self, and audience, and we can "unpack" the grammatical resources 
they select to make their moral points clear to the listener. Interpretation requires close analysis of how narrators position audiences (and, reciprocally, how the audience positions the narrator). Identities are constituted through such performative actions. Audiences, of course, may "read" events differently than narrators do, resulting in contested meanings.

\section{THE “TRUTHS” OF PERSONAL NARRATIVE}

I stated at the outset that my approach to narrative analysis does not assume objectivity but, instead, positionality and subjectivity. The perspectives of both narrator and analyst can come into view. As the Personal Narrative Group (1989) articulates, "truths" rather than "the truth" of personal narrative is the meaningful semantic distinction

Not all scholars who work with personal narratives would agree. Daniel Bertaux (1995:2), for example, believes that "every life story contains a large proportion of factual data which can be verified" (e.g. with dates and places of biographical events). Locating himself in the "realist" research tradition, he argues that informants' stories collected from the same milieu can serve as documentary sources for investigating the world "out there." Although acknowledging that informants do not "tell us the whole truth and nothing but the truth", by collecting many stories from the same milieu Bertaux claims to uncover "recurrent patterns concerning collective phenomena or share collective experience in a particular milieu" (p. 2).

Those working from social constructionist or performative perspectives approach the issue of truth differently. Verification of the "facts" of lives is less salient than 
understanding the changing meaning of events for the individuals involved — and how these, in turn, are located in history and culture. Personal narratives are, at core, meaning-making units of discourse. They are of interest precisely because narrators interpret the past in stories, rather than reproduce the past as it was.

Returning to Gita's narrative account of infertility, it is irrelevant whether the events "really" occurred as she reports them. She was one informant in a larger project about identity for childless women, and Gita clearly performs one strategic solution to the problem infertility poses for her gender identity: she is "perfectly" normal, with "no defect at all." As argued earlier, it is possible to question her causal attributions. It also goes without saying that the passage of time since the miscarriages has softened their emotional impact, and consequently she can be silent about emotions. As all narrators do, she presents past events from the vantagepoint of present realities and values. Not unlike other women I interviewed who were beyond childbearing age, she minimizes the significance of biological motherhood, and emphasizes instead occupational and political identities.

The "truths" of narrative accounts lie not in their faithful representation of a past world, but in the shifting connections they forge between past, present, and future. The complex relationships between narrative, time, and memory are currently a vital topic of research and theorizing (Freeman 1998, forthcoming; for a review see Hinchman and Hinchman 1997).

Storytelling among those with chronic illnesses offers a case in point. Serious illness interrupts lives (Charmaz 1991) and occasions the "call for stories" (Frank 1995:53). Friends want to know "what happened" and stories provide maps for the ill 
themselves "to repair the damage that illness has done to the ill person's sense of where she is in life, and where she may be going." Yet the storylines or plots into which the seriously ill pour their experience (and those oncologists use with patients) may be at variance with biomedical plots. Patients with incurable cancers, for example, construct "restitution" narratives that suggest positive end points, while others represent themselves in "chaos" narratives, where continuity between past and future is unclear (Frank 1995). Oncologists are often asked about time, and they construct narratives of hope for families that blur endings and leave the future ambiguous (Good et al. 1994). For both practitioners and patients, a storyline locates the threatening illness in an imagined life trajectory (Mattingly 1994; Riessman 1990a).

Meanings of life events are not fixed or constant, but evolve, influenced by subsequent life events. "As we access and make sense of events and experiences in our pasts and how they are related to our current selves, we change their meanings" (Mishler 1999b:5): ends beget beginnings (Mishler 2000). Personal narratives - the stories we tell to ourselves, to each other, and to researchers--offer a unique window into these formations and reformations:

We continually restory our pasts, shifting the relative significance of different events for whom we have become, discovering connections we had previously been unaware of, repositioning ourselves and others in our networks of relationships (Mishler 1999b:5).

A useful way to see how identities can shift over time is to look at "turning points" in stories - moments when the narrator signifies a radical shift in the expected course of a life. For example, in my research on divorce, it was common to hear 
informants report moments when they retrospectively realized "this is it." The marital relationship had crossed a line that was beyond repair. Such "turning points" in lives occurred often after physical violence, directed either toward the spouse or a child. One woman said “That was the last straw. You just don’t hit me...I wasn't going to stay around to be hit again." Another woman, who had been physically abused for years, spoke of "the final blow", her husband "punched our oldest daughter across the living room...if he was going to start doing that to the kids, that was it." A divorcing man told a long narrative about his wife's open infidelity, culminating in a moment when he hit her. He said to himself, "this is it...there wasn't any reasons to be there other than to hurt" (Riessman 1990b). Such "turning points" fundamentally change the meaning of past experiences, and consequently an individual's identity: "they open up directions of movement that were not anticipated by and could not be predicted by their pasts"-an insight Mishler (1999b:7-8) applies to the narratives of sexual abuse survivors. Past abuse is given new significance as women move out of destructive relationships and construct new identities.

The "trustworthiness" of narrative accounts cannot be evaluated using traditional correspondence criteria. There is no canonical approach to validation in interpretive work, no recipes or formulas. (For a review of several approaches that may be useful in certain instances, see Riessman 1993:64-69). 
I began this paper with a story about my early encounters during research interviews with narrative accounts of disrupted lives. Since that time, many investigators have given a name to my problem, and offered analytic solutions for working with narrative accounts that do not require fragmenting them. The field of narrative analysis is rapidly moving, and no review can be complete and summarize the many types of work that are evident today. I purposively bounded the field, emphasizing primarily the performative dimension, but also pointed the reader to sources outside this tradition. (For reviews and typologies of research strategies see Cortazzi 1993; Langellier 1989; Mishler 1995; Riessman 1993).

Narrative analysis has its critics (Atkinson 1997; Atkinson and Silverman 1997). The methods are not appropriate for studies of large numbers of nameless, faceless subjects. The approach is slow and painstaking, requiring attention to subtlety: nuances of speech, the organization of a response, relations between researcher and subject, social and historical contexts. Not suitable for investigators who seek an easy and unobstructed view of subjects' lives, the analytic detail may seem excessive to those who view language as a transparent medium.

Narrative methods can be combined with other forms of qualitative analysis (for an example, see Riessman 1990b), even with quantitative analysis. ${ }^{\text {ix }}$ Some fancy epistemological footwork is required because the interpretive perspective that typically underlies narrative work is very different than the realist assumptions of many forms of qualitative analysis and certainly of quantification. Combining methods forces investigators to confront troublesome philosophical issues and to educate readers about them. Science cannot be spoken in a singular universal voice. Any methodological 
standpoint is, by definition, partial, incomplete, and historically contingent. Diversity of representations in needed. Narrative analysis is one approach, not a panacea, suitable for some situations, not others. It is a useful addition to the stockpot of social science methods, bringing critical flavors to the fore than otherwise get lost. Narrative analysis allows for systematic study of personal experience and meaning. The approach enables investigators to study the "active, self-shaping quality of human thought, the power of stories to create and refashion personal identity" (Hinchman and Hinchman 1997:xiv).

Narratives are a particularly significant genre for representing and analyzing identity in its multiple guises in different contexts. The methods allow for systematic study of experience and (for feminist researchers) the changing meaning of conditions that affect women disproportionately—domestic violence, reproductive illness, and poverty. Personal narratives provide windows into lives that confront the constraints of circumstances. Attention to personal narratives in interviews opens discursive spaces for research subjects. We can represent them as agents acting in life worlds of moral complexity. 
i There are, of course, other narrative sites besides interviews. For examples of so-called "natural" storytelling, see Ochs, Smith, Taylor (1989) and Polanyi (1995).

ii There is lively philosophical debate about whether primary experience is "disordered," that is, whether narrators create order out of chaos. See Hinchman and Hinchman (1997:xix-xx).

iii Transcription conventions and stanza structure (the organization of lines about the same topic in poetic stanzas) are adapted from Gee (1986). Because of its direct performative reference, I have organized the narrative into "scenes", rather than strophes as Gee does. 
I have deleted brief exchanges between Gita and me, questions I ask to clarify what she has said. They are marked "=".

${ }^{\text {iv }}$ Transcriptions, of course, are themselves theory-laden: how we chose to represent spoken dialogue is not independent of theoretical goals. On this point, see Ochs (1979), Mishler (1991), Kvale (1996: Chapter 9), Poland (1995).

${ }^{\vee}$ See Capps and Ochs (1995) for a compelling analysis of conversations with a single narrator over several years. It combines textual and conversational approaches to study the discourse of a woman suffering from agoraphobia—severe panic attacks.

vi The verb construction "had to" is, in fact, ambiguous. It might refer to others' expectations that Gita participate in the political demonstration, a consequence of her leadership role in the community; or it might refer to an "inner" compulsion to participate, arising out of her own political convictions and priorities. The narrative context supports the latter interpretation.

vii Infertility is a family event in the Indian context, and husbands' relatives often suggest and initiate treatment for the daughter-in-law, including medical and religious cures (Riessman 2000a, 2000b).

viii The actual responsibility for infertility in this and the other cases is unclear. India's infertility clinics require both spouses to be tested, and about a third of the time the 
problem lies in his sperm. Elsewhere (2000b) I have described women's management of male responsibility — they do not disclose it to deflect stigma but, in an effort to keep families together, absorb the "fault" themselves.

9 The material in this paragraph is adapted from Riessman (1993:70).

\section{REFERENCES}

Atkinson, P. 1997. "Narrative Turn or Blind Alley?” Qualitative Health Research 7(3):325-344.

Atkinson, P. and D. Silverman. 1997. “Kundera's 'Immortality': The Interview Society and the Invention of Self." Qualitative Inquiry 3:304-325.

Attanucci, J. 1991. "Changing Subjects: Growing Up and Growing Older." Journal of Moral Education 20:317-328. 
Bamberg, M.G.W. and A. McCabe. 1998. “Editorial.” Narrative Inquiry 8(1):iii-v.

Bamberg, M.G.W., ed. 1997a. “Oral Versions of Personal

Experience: Three Decades of Narrative Analysis.” Special issue. Journal of Narrative and Life History 7(1-4).

Bamberg, M. G. W. 1997b. "Positioning Between Structure and Performance." Journal of Narrative and Life History 7(1-4):335-342.

Bauman, R. 1986. Story, Performance, and Event: Contextual Studies of Oral Narrative. Cambridge: Cambridge University Press, 1986.

Behar, R. 1993. Translated Woman: Crossing the Border with Esperanza's Story. Boston: Beacon.

Bell, S.E. 1988. "Becoming a Political Woman: The Reconstruction and Interpretation of Experience Through Stories." In Gender and Discourse: The Power of Talk, edited by A.D. Todd and S. Fisher. Norwood, NJ: Ablex Publishing Corporation.

Bell, S.E. 1999. "Narratives and Lives: Women's Health Politics and the Diagnosis of Cancer for DES Daughters." Narrative Inquiry 9(2):1-43. 
Bell, S.E. 2000. “Experiencing Illness In/and Narrative.” In Handbook of Medical Sociology, fifth edition, edited by C.E. Bird, P. Conrad, A.M. Fremont. Upper Saddle River, NJ: Prentice Hall.

Bertaux, D. 1995. “A Response to Thierry Kochuyt's 'Biographic and Empiricist Illusions: A Reply to Recent Criticism'.” Biography and Society Newsletter: 2-6. Research Committee \#38, International Sociological Association.

Boje, D.M. 1991. “The Storytelling Organization: A Study of Story Performance in an Office-supply Firm.” Administrative Science Quarterly 36:106-126.

Bruner, J. 1990. Acts of Meaning. Cambridge: Harvard Univ. Press.

Bruner, J. 1986. Actual Minds, Possible Worlds. Cambridge: Harvard Univ. Press.

Capps, L. and E. Ochs. 1995. Constructing Panic: The Discourse of Agoraphobia. Cambridge: Harvard Univ. Press.

Carr, D. 1986. Time, Narrative, and History. Bloomington: Indiana Univ. Press. 
Charmaz, K. 1991. Good Days, Bad Days. Rutgers Univ. Press.

Charon, R. 1986. "To Render the Lives of Patients." Literature and Medicine $5: 58-74$

Chase, S.E. 1995. Ambiguous Empowerment: The Work Narratives of Women School Superintendents. Amherst: Univ. of Mass.

Cortazzi, M. 1993. Narrative Analysis. London: Falmer Press.

Cronon, W. 1992. “A Place for Stories: Nature, History, and Narrative.” Journal of American History 78:1347-1376.

Cussins, C.M. 1998. “Ontological Choreography: Agency for Women Patients in an Infertility Clinic.” In Differences in Medicine: Unraveling Practices, Techniques, and Bodies, edited by M. Berg and S. Mol. Durham NC: Duke Univ. Press.

Dean, R.G. 1995. "Stories of AIDS: The Use of Narrative as an Approach to Understanding in an AIDS Support Group.” Clinical Social Work Journal 23(3): 287-304.

DeVault, M. L. 1999. Liberating Method: Feminism and Social Research. 
Philadelphia: Temple Univ. Press.

DeVault, M.L. 1991. “Talking and Listening from Wmen's Standpoint: Feminist Strategies for Interviewing and Analysis." Social Problems 37:96-116.

Freeman, M. Forthcoming. "The Presence of What is Missing: Memory, Poetry, and the Ride Home." In Between Fathers and Sons: Critical Incident Narratives on the Development of Men's Lives. edited by R.J. Pellegrini and T.R. Sarbin. Thousand Oaks: Sage.

Freeman, M. 1998. "Mythical Time, Historical Time, and the Narrative Fabric of the Self." Narrative Inquiry 8(1):1-24.

Frank, A W. 1995. The Wounded Storyteller: Body, Illness, and Ethics. Chicago: Univ. of Chicago Press.

Gamson, W.A. 1999. "How Story Telling can be Empowering." Paper presented at conference on Toward a Sociology of Culture and Cognition, Rutgers Univ., Nov. 12-13, 1999.

Gee, J.P. 1986. "Units in the Production of Narrative Discourse." Discourse Processes 9:391-422. 
Gee, J.P. 1991. “A Linguistic Approach to Narrative.” Journal of Narrative and Life History 1:15-39.

Goffman, E. 1969. The Presentation of Self in Everyday Life. NY: Penguin.

Goffman, E. 1981. Forms of Talk. Oxford: Blackwell.

Good, M-J. D.V., T. Munakata, Y. Kobayashi, C. Mattingly, B.J. Good. 1994. “Oncology and Narrative Time." Social Science and Medicine 38(6): $855-862$.

Greenhalgh, T. and B. Hurwitz, eds. 1998. Narrative Based Medicine: Dialogue and Discourse in Clinical Practice. London: BMJ Books.

Harre, R. and L. van Langenhove, eds. 1999. Positioning Theory. Malden MA: Blackwell.

Hinchman, L.P. and S.K. Hinchman, eds. 1997. Memory, Identity, Community: The Idea of Narrative in the Human Sciences. Albany: State Univ. of N.Y. Press.

Holstein, J.A. and J. F. Gubrium. 2000. The Self We Live By: Narrative Identity in a Postmodern World. New York: Oxford Univ. Press. 
Hunter, K.M. 1991. Doctor's Stories: The Narrative Structure of Medical Knowledge. Princeton: Princeton Univ. Press.

Hyden, L.C. 1997. “Illness and Narrative.” Sociology of Health \& Illness 19:48-69.

Jefferson, G. 1979. "Sequential Aspects of Storytelling in Conversation. In Studies in the Organization of Conversational Interaction, edited by J. Schenkein. NY: Academic Press.

Josselson, R. and A. Lieblich, eds. 1993. The Narrative Study of Lives. Newbury Park, CA: Sage.

Kaminsky, M. 1992. "Introduction.” In Remembered Lives: The Work of Ritual, Storytelling, and Growing Older, by Barbara Myerhoff with D. Metzger, J. Ruby, and V. Tufte. Ann Arbor: Univ. of Michigan Press.

Kleinman, A. 1988. The Illness Narratives: Suffering, Healing, and the Human Condition. New York: Basic Books.

Kvale, S. 1996. InterViews. London: Sage. 
Labov, W. 1982. "Speech Actions and Reactions in Personal Narrative.” In Analyzing Discourse: Text and Talk, edited by D. Tannen. Washington D.C.: Georgetown University Press.

Laird, J. 1988. "Women and Stories: Restorying Women's Self-constructions.” In Women in Families: A Framework for Family Therapy, edited by M. McGoldrick, C.Anderson, and F.Walsh. New York: Norton.

Langellier, K. 2001. “'You're Marked': Breast Cancer, Tattoo and the Narrative Performance of Identity." In Narrative and Identity: Studies in Autobiography, Self, and Culture, edited by J. Brockmeier and D. Carbaugh. Amsterdam and Philadelphia: John Benjamins.

Langellier, K. 1989. "Personal Narratives: Perspectives on Theory and Research.” Text and Performance Quarterly 9(4):243-276.

Laslett, B. 1999. "Personal Narratives as Sociology." Featured essay, Contemporary Sociology 28(4):391-401.

Legal Storytelling. 1989. [Special issue]. Michigan Law Review 87(8).

Linde, C. 1993. Life Stories: The Creation of Coherence. New York: Oxford Univ. Press. 
Mattingly, C. and L. C. Garro, eds. 2000. Narrative and Cultural Construction of Illness and Healing. Berkeley: Univ. of California Press.

Mattingly, C. 1998. Healing Dramas and Clinical Plots: The Narrative Structure of Experience. New York: Cambridge Univ. Press.

Mattingly, C. 1994. “The Concept of Therapeutic 'Emplotment.” Social Science and Medicine 38(6):811-822.

McLeod, J. 1997. Narrative and Psychotherapy. Thousand Oaks CA: Sage.

Michaels, S. 1981. “'Sharing Time’: Children's Narrative Styles and Differential Access to Literacy." Language and Society 10:423-442.

Mills, C.W. 1959. The Sociological Imagination. New York: Oxford Univ. Press.

Mishler, E.G. 2000. "Narrative and the Paradox of Temporal Ordering: How Ends Beget Beginnings.” Paper presented at conference on Discourse and Identity, Clark University.

Mishler, Elliot G. 1999a. Storylines: Craftartists' Narratives of Identity. Cambridge: Harvard Univ. Press. 
Mishler, E.G. 1999b. “Time's Double Arrow: Re-presenting the Past in Life History Studies.” Paper presented at Radcliffe Murray Center conference, Lives in Context: the Study of Human Development," Cambridge MA, November 12-13.

Mishler, E.G. 1997. "Narrative Accounts in Clinical and Research Interviews." In The Construction of Professional Discourse, edited by B-L. Gunnarsson, P. Linell, and B. Norberg. London: Longman.

Mishler, E.G. 1995. "Models of Narrative Analysis: A Typology." Journal of Narrative and Life History 5(2):87-123.

Mishler, E.G. 1991. "Representing Discourse: The Rhetoric of Transcription." Journal of Narrative and Life History 1:255-280.

Mishler, E.G. 1986. Research Interviewing: Context and Narrative. Cambridge: Harvard Univ. Press.

Mumby, D.K. 1993. Narrative and Social Control: Critical Perspectivves. Newbury Park: Sage.

Myerhoff, B. 1978. Number Our Days. NY: Simon and Schuster. 
Ochs, E., R. Smith, and C. Taylor. 1989. "Dinner Narratives as Detective Stories." Cultural Dynamics 2:238-257.

Ochs, E. 1979. “Transcription as Theory.” In Developmental Pragmatics, edited by E. Ochs and B.B. Schieffelin. New York: Academic Press.

Personal Narratives Group. 1989. “Truths.” In Interpreting Women’s Lives. Bloomington: Indiana Univ. Press.

Plummer, K. 1995. Telling Sexual Stories: Power, Change and Social Worlds. New York: Routledge.

Poland, B. 1995. "Transcription Quality as an Aspect of Rigor in Qualitative Research." Qualitative Inquiry 1:290-310.

Polanyi, L. 1985. “Conversational Storytelling.” In Handbook of Discourse Analysis, edited by T.A. Van Dijk. London: Academic Press.

Polkinghorne, D.E. 1988. Narrative Knowing and the Human Sciences Albany: State Univ. of N.Y. Press.

Riessman, C.K. 2000a “'Even if we don't have children [we] can live': 
Stigma and Infertility in South India." In Narrative and Cultural Construction of Illness and Healing, edited by C. Mattingly and L. C. Garro. Berkeley: Univ. of California Press.

Riessman, C.K. 2000b. "Stigma and Everyday Resistance Practices: Childless Women in South India.” Gender \& Society 14(1):111-135.

Riessman, C.K. 1993. Narrative Analysis. Qualitative Research Methods Series, No. 30. Newbury Park, CA: Sage.

Riessman, C.K. 1990a. "Strategic Uses of Narrative in the Presentation of Self and Illness." Social Science and Medicine 30:1195-1200.

Riessman, C.K. 1990b. Divorce Talk: Women and Men Make Sense of Personal Relationships. New Brunswick NJ: Rutgers University Press.

Riessman, C.K. 1987. "When Gender is not Enough: Women Interviewing Women." Gender and Society 1:172-207.

Rosaldo, R. 1989. Culture and Truth: The Remaking of Social Analysis. Boston: Beacon Press.

Rosenwald, G. and R. Ochberg, eds. 1992. Storied Lives: Cultural Conditions 
of Self Understanding. New Haven: Yale Univ. Press.

Sandelowski, M. 1991. “Telling Stories: Narrative Approaches in Qualitative Research.” Image: Journal of Nursing Scholarship 23(3):161-166.

Sarbin, T.R., ed. 1986. Narrative Psychology: The Storied Nature of Human Conduct. New York: Praeger.

Skultans, V. 1999. "Narratives of the Body and History: Illness in Judgement on the Soviet Past." Sociology of Health \& Illness 21:310-328.

White, H. 1987. The Content of the Form: Narrative Discourse and Historical Representation. Baltimore: Johns Hopkins Univ. Press.

White, M. and D. Epston. 1990. Narrative Means to Therapeutic Ends. NY: Norton.

Williams, G. 1984. "The Genesis of Chronic illness: Narrative Re-construction." Sociology of Health \& Illness 6(2):175-200.

Young, K. G. 1987. Taleworlds and Storyrealms: The Phenomenology of Narrative. Boston: Martins Nijhoff. 


\section{TRANSCRIPT 1 (ID 27:8-9)}

C: Now I am going to go back and ask some specific questions. Were you ever pregnant?

G: Pregnant means-- You see it was 3 years [after the marriage] SCENE 1

then I approached [name of doctor]

then she said it is not a viable - [pregnancy].

So she asked me to undergo this operation, this D\&C

and she wanted to examine him [husband] also.

Then the second time in 1974-in 75,

SCENE 2 next time--four months.

Then she wanted [me] to take bed rest advised me to take bed rest.

Because I already told you

SCENE 3

it was during that period that [name] the socialist leader

led the gigantic procession against Mrs. Indira Gandhi, the Prime Minister of India, in Delhi.

And I was a political leader [names place and party]

I had to participate in that.

So I went by train to Delhi

but returned by plane.

After the return I was in [name] Nursing Home

for 16 days bleeding.

And so he [husband] was very angry

SCENE 4

he said "do not go for any social work

do not be active" this and that.

But afterwards I never became-[pregnant]

Then my in-laws, they are in [city]

SCENE 5

they thought I had some defect, really speaking.

So they brought me to a gynecologist,

one [name], one specialist.

She took three hours to examine me

and she said "you are perfectly- [normal], no defect at all" 
even though I was 40 or 41 then.

"So I have to examine your husband."

Then I told her [doctor] "You just ask his sister."

She was- his sister was with me in [city].

So I asked her to ask her to bring him in.

He will not come.

Then we went to the house

so then I said "Dr. [name] wants to see you."

Then he [husband] said "No, no, I will not go to a lady doctor."

Then she [sister-in-law] said she would not examine him

they had to examine the-what is it?--the sperm in the laboratory.

But he did not allow that. 